JIBEKA

Jurnal IImiah Bisnis dan Ekonomi Asia

ISSN 2620-875X (Online) ISSN 0126-1258 (Print)

http://jurnal.stie.asia.ac.id

Hal. 66-75

\title{
Pengaruh Earning Per Share, Debt To Equity Ratio dan Return On Equity Terhadap Saham LQ45
}

\author{
Rini Trah Purboyanti \\ Program Studi Akuntansi, Fakultas Ekonomi \& Bisnis, Universitas Brawijaya \\ Alamat e-mail: trahyoo@yahoo.co.id \\ Ahmad Nizar Yogatama \\ Program Studi Manajemen, Sekolah Tinggi Ilmu Ekonomi Asia \\ Alamat e-mail: nizaryogatama@asia.ac.id
}

\begin{abstract}
This study aims to analyze how much Earning Per Share, Debt to Equity Ratio and Return On Equity to stock prices in companies indexed by the 2015-2017 LQ45 period. The population of this study is the LQ45 company that is consistently indexed in 2015-2017. The sample of this study uses purposive sampling. The sample in this study were 35 companies. The type of data used is secondary data derived from a summary of financial statement records. The analysis technique uses multiple linear regression analysis. The results of the study found that Earning Per Share had an effect on stock prices, while Debt to Equity Ratio and Return On Equity had no effect on stock prices for LQ45 indexed companies consistently in the 2015-2017 period.
\end{abstract}

Keywords: Stock Price, Earning Per Share, Debt to Equity Ratio, Return On Equity

\begin{abstract}
Abstrak
Penelitian ini bertujuan untuk menganalisis seberapa besar Earning Per Share, Debt to Equity Ratio dan Return On Equity terhadap harga saham pada perusahaan yang terindeks LQ45 periode 2015-2017. Populasi penelitian ini adalah perusahaan LQ45 yang secara konsisten terindeks tahun 2015-2017. Sampel penelitian ini menggunakan purposive sampling. Sampel dalam penelitian ini sebanyak 35 perusahaan. Jenis data yang digunakan adalah data sekunder yang berasal dari ringkasan catatan laporan keuangan. Teknik analisis menggunakan analisis regresi linier berganda. Hasil penelitian menemukan bahwa Earning Per Share berpengaruh terhadap harga saham, sedangkan Debt to Equity Ratio dan Return On Equity tidak berpengaruh terhadap harga saham untuk perusahaan terindeks LQ45 secara konsisten periode 2015-2017.
\end{abstract}

Kata Kunci: Harga Saham, Earning Per Share, Debt to Equity Ratio, Return On Equity

\section{Pendahuluan}

Perkembangan dunia usaha selalu menciptakan perubahan pasar dan meningkatkan persaingan antar perusahaan. Peningkatan persaingan menuntut perusahaan untuk menjual sahamnya ke pasar modal (Capital Market). Hal ini kemudian menjadi dasar bahwa semua perusahaan memiliki tujuan untuk memaksimalkan keuntungan para pemegang saham, walaupun hal ini tidak mudah dilakukan karena harga saham mengalami fluktuasi setiap hari (Hasanah, Wahono, \& Salim, 2017). Fluktuasi merupakan hal wajar bagi harga saham, tidak terkecuali bagi saham perusahaan yang terindeks LQ45. 


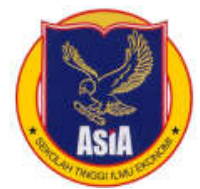

JIBEKA

Jurnal IImiah Bisnis dan Ekonomi Asia

ISSN 2620-875X (Online) ISSN 0126-1258 (Print)

http://jurnal.stie.asia.ac.id

Hal. $66-75$

Indeks LQ45 merupakan sekumpulan perusahaan yang memiliki kapitalisasi pasar yang baik serta saham paling likuid. Berdasarkan hal tersebut, maka saham perusahaan yang tergabung dalam indeks LQ45 memiliki nilai transaksi yang tinggi (Egam, llat, \& Pangerapan, 2017). Namun, realita menunjukkan bahwa tidak ada jaminan untuk saham paling likuid di Bursa Efek Indonesia, seperti saham indeks LQ45. Indeks LQ45 pada tahun 2017 mengalami penurunan disebabkan oleh Capital Outflow dana asing, yaitu kondisi dimana investor asing cenderung mengalihkan dananya ke pasar obligasi. Walaupun terjadi pengalihan dana yang menyebabkan penurunan indeks LQ45 oleh investor asing ke pasar obligasi, namun sejumlah emiten di Bursa Efek Indonesia BEl tercatat memiliki Debt to Equity Ratio di atas 100\%. Hal terpenting bagi pelaku pasar adalah mencermati kinerja dan prospek emiten ke depan.

Berdasarkan Gambar 1, dapat dilihat bahwa harga saham indeks LQ45 meningkat sejak tahun 2017 hingga 2018 dan mengalami penurunan sejak awal tahun 2018 hingga saat ini. Peningkatan harga saham LQ45 disebabkan oleh kondisi pasar dan kinerja perusahaan yang dapat dinilai dari Debt to Equity Ratio, Earning Per Share dan Return On Equity. Data tersebut dapat dilihat pada Tabel 1.

Earning Per Share merupakan rasio yang banyak diperhatikan oleh calon investor, karena informasi Earning Per Share merupakan informasi yang dianggap paling mendasar dan dapat menggambarkan prospek earning perusahaan masa depan. Pada umumnya manajemen perusahaan, pemegang saham biasa dan calon pemegang saham tertarik akan Earning Per Share, karena hal ini menggambarkan jumlah rupiah yang diperoleh untuk setiap lembar saham biasa. Penelitian yang dilakukan Egam et al., (2017) menemukan bahwa perusahaan yang tergabung dalam LQ45 periode 2013-2015 memiliki Earning Per Share yang berpengaruh terhadap harga saham (Egam et al., 2017). Sementara itu, Lacinka et al., (2018) melakukan penelitian tentang harga saham perusahaan yang tergabung dalam LQ45 periode 2012-2015 menemukan bahwa Earning Per Share berpengaruh terhadap harga saham (Lacinka, Fathoni, \& Gagah, 2018). Dirangkai berdasarkan hasil - hasil penelitian terdahulu, sehingga dapat ditarik hipotesis 1 penelitian ini adalah Earning Per Share (EPS) berpengaruh terhadap Harga Saham.

Angka Debt to Equity Ratio menunjukkan struktur modal lebih mengutamakan utang daripada modal sendiri. Implikasi Debt to Equity Ratio adalah pemegang saham dapat mempertahankan pengendalian atas perusahaan dengan investasi yang terbatas, risiko perusahaan sebagian besar ada pada kreditur serta pengembalian atas modal pemilik semakin kecil. Berdasarkan Tabel 1, 25 Perusahaan yang terindeks LQ45 memiliki Debt to Equity Ratio menurun selama periode 2015-2017. Penurunan Debt to Equity Ratio menunjukkan bahwa return saham meningkat karena kemampuan perusahaan dalam memperoleh laba berbanding terbalik dengan return saham (Masruri, 2012). Hal tersebut didukung oleh Kumaidi \& Asandimitra (2017) dan Ramadhani \& Arnomo pada (2014) menemukan jika Debt to Equity Ratio berpengaruh terhadap harga saham, namun bertantangan dengan Sriwahyuni \& Saputra (2017) karena Debt to Equity Ratio tidak berpengaruh terhadap harga saham (Kumaidi \& Asandimitra, 2017; Ramadhani \& Arnomo, 2014; Sriwahyuni \& Saputra, 2017). Dirangkai berdasarkan hasil - hasil penelitian terdahulu, sehingga dapat ditarik hipotesis 2 penelitian ini adalah Debt to Equity Ratio berpengaruh terhadap harga saham. 


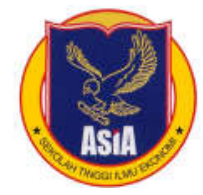

JIBEKA

Jurnal IImiah Bisnis dan Ekonomi Asia

ISSN 2620-875X (Online) ISSN 0126-1258 (Print)

http://jurnal.stie.asia.ac.id

Hal. $66-75$

Tabel 1. Debt to Equity Ratio, Earning Per Share, Return On Equity

\begin{tabular}{|c|c|c|c|c|c|c|c|c|c|c|}
\hline \multirow{2}{*}{$\mathrm{NO}$} & \multirow{2}{*}{ CODE } & \multicolumn{3}{|c|}{ Debt to Equity Ratio } & \multicolumn{3}{|c|}{ Earning Per Share } & \multicolumn{3}{|c|}{ Return On Equity } \\
\hline & & 2015 & 2016 & 2017 & 2015 & 2016 & 2017 & 2015 & 2016 & 2017 \\
\hline 1 & $\mathrm{ADHI}$ & 2.25 & 2.69 & 3.40 & 130.59 & 88.49 & 57.69 & 9.01 & 5.79 & 3.70 \\
\hline 2 & ADRO & 0.78 & 0.72 & 0.67 & 65.74 & 140.56 & 204.71 & 4.50 & 9.00 & 13.11 \\
\hline 3 & AKRA & 1.09 & 0.96 & 0.95 & 262.36 & 253.22 & 254.40 & 14.53 & 12.97 & 12.83 \\
\hline 4 & ANTM & 0.66 & 0.63 & 0.70 & $(59.96)$ & 2.70 & $(13.79)$ & $(7.87)$ & 0.35 & $(1.84)$ \\
\hline 5 & ASII & 0.94 & 0.87 & 0.89 & 357.31 & 374.37 & 466.39 & 12.34 & 13.08 & 14.82 \\
\hline 6 & BBCA & 5.60 & 4.97 & 4.77 & 730.83 & 835.76 & 683.09 & 20.12 & 18.30 & 13.21 \\
\hline 7 & BBNI & 5.26 & 5.52 & 5.79 & 486.18 & 608.02 & 730.16 & 11.65 & 12.78 & 13.65 \\
\hline 8 & BBRI & 6.76 & 5.84 & 5.73 & 1029.53 & 1061.88 & 235.08 & 22.46 & 17.86 & 17.36 \\
\hline 9 & BBTN & 11.40 & 10.20 & 11.06 & 174.91 & 247.30 & 285.88 & 13.35 & 13.69 & 13.98 \\
\hline 10 & BMRI & 6.16 & 5.38 & 5.22 & 871.50 & 591.71 & 442.28 & 17.70 & 9.55 & 12.61 \\
\hline 11 & BSDE & 0.63 & 0.57 & 0.57 & 122.17 & 105.86 & 268.45 & 10.64 & 8.37 & 17.70 \\
\hline 12 & HMSP & 0.19 & 0.24 & 0.50 & 2227.36 & 215.40 & 0 & 32.37 & 37.34 & 30.17 \\
\hline 13 & ICBP & 0.62 & 0.56 & 0.56 & 514.62 & 308.73 & 260.82 & 17.84 & 19.63 & 15.34 \\
\hline 14 & INCO & 0.25 & 0.21 & 0.20 & 74.49 & 2.58 & (20.82) & 2.75 & 0.10 & $(0.84)$ \\
\hline 15 & INDF & 1.13 & 0.87 & 0.92 & 338.02 & 472.02 & 373.29 & 8.60 & 11.99 & 9.39 \\
\hline 16 & & 0.16 & 0.15 & 0.14 & 1183.48 & 1051.37 & 382.07 & 18.25 & 14.81 & 5.83 \\
\hline 17 & JSMR & 1.97 & 2.27 & 3.31 & 213.14 & 243.97 & 273.91 & 10.67 & 11.04 & 11.40 \\
\hline 18 & KLBF & 0.25 & 0.22 & 0.22 & 42.76 & 49.06 & 37.96 & 18.81 & 18.86 & 13.66 \\
\hline 19 & LPKR & 1.18 & 1.07 & 1.00 & 44.38 & 53.18 & 37.45 & 5.41 & 5.56 & 3.29 \\
\hline 20 & LPPF & 2.52 & 1.62 & 1.33 & 610.31 & 692.17 & 653.57 & 160.99 & 108.86 & 81.92 \\
\hline 21 & $\mathrm{~N}$ & 0.51 & 0.50 & 0.50 & 83.05 & 95.87 & 78.58 & 13.35 & 15.63 & 12.44 \\
\hline 22 & MYRX & 0.31 & 0.40 & 0.43 & 0.91 & 0.85 & 0.46 & 0.23 & 1.13 & 0.53 \\
\hline 23 & PGAS & 1.15 & 1.16 & 0.97 & 242.58 & 168.67 & 80.00 & 13.32 & 9.73 & 4.64 \\
\hline 24 & PTBA & 0.82 & 0.76 & 0.51 & 883.59 & 870.69 & 1139.62 & 21.93 & 19.18 & 20.64 \\
\hline 25 & PTPP & 2.74 & 1.89 & 1.83 & 174.62 & 185.72 & 180.39 & 16.52 & 10.67 & 8.95 \\
\hline 26 & PWON & 0.99 & 0.88 & 0.83 & 29.08 & 36.97 & 32.03 & 14.81 & 16.16 & 12.51 \\
\hline 27 & SCMA & 0.34 & 0.30 & 0.21 & 104.20 & 102.65 & 74.80 & 44.57 & 40.78 & 23.54 \\
\hline 28 & SMGR & 0.39 & 0.45 & 0.57 & 762.28 & 762.30 & 246.09 & 16.49 & 14.83 & 4.88 \\
\hline 29 & SRIL & 1.83 & 1.86 & 1.78 & 43.88 & 42.90 & 34.28 & 20.11 & 17.93 & 12.67 \\
\hline 30 & SSMS & 1.30 & 1.07 & 1.23 & $(2.75)$ & 62.12 & 25.10 & 19.35 & 17.13 & 6.50 \\
\hline 31 & TLKM & 0.78 & 0.70 & 0.72 & 153.66 & 171.93 & 177.80 & 24.96 & 27.64 & 23.53 \\
\hline 32 & UNTR & 0.57 & 0.50 & 0.73 & 1033.07 & 1341.03 & 1984.64 & 7.11 & 11.98 & 16.14 \\
\hline 33 & UNVR & 2.26 & 2.56 & 2.65 & 766.95 & 837.57 & 918.03 & 121.22 & 135.85 & 135.40 \\
\hline 34 & WIKA & 2.60 & 1.46 & 2.12 & 114.32 & 135.01 & 151.18 & 12.93 & 9.51 & 9.27 \\
\hline 35 & WSKT & 2.12 & 2.66 & 3.30 & 77.18 & 133.58 & 309.54 & 10.80 & 10.81 & 18.46 \\
\hline
\end{tabular}

Return on Equity mengukur kemampuan perusahaan menghasilkan laba bersih berdasarkan modal tertentu. Kenaikan rasio ini berarti terjadi kenaikan laba bersih dari perusahaan yang bersangkutan. Jadi, para investor dapat menggunakan indikator Return on Equity sebagai bahan pertimbangan dalam memilih saham atau menanamkan modalnya, 


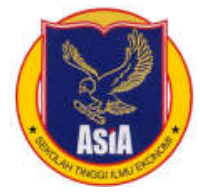

JIBEKA

Jurnal IImiah Bisnis dan Ekonomi Asia

ISSN 2620-875X (Online) ISSN 0126-1258 (Print)

http://jurnal.stie.asia.ac.id

Hal. 66-75

karena rasio ini menunjukkan bahwa dengan kinerja manajemen meningkat maka perusahaan dapat mengelola sumber dana pembiayaan operasional secara efektif untuk menghasilkan laba bersih sehingga saham perusahaan banyak diminati investor. Kumaidi \& Asandimitra (2017) menemukan Return On Equity hanya berpengaruh terhadap harga saham khusus sektor perbankan dengan nilai kapitalisasi kecil, sedangkan perbankan dengan nilai kapitalisasi besar tidak berpengaruh (Kumaidi \& Asandimitra, 2017). Saryadi (2016) menemukan Return on Equity tidak berpengaruh terhadap harga saham sektor pertambangan (Saryadi, 2016). Kemudian, Halim \& Faisal (2016) menemukan Return On Equity berpengaruh terhadap harga saham industri manufaktur (Halim, Basri, \& Faisal, 2016). Terakhir adalah Sriwahyuni \& Saputra (2017) menemukan tidak terdapat pengaruh Return On Equity terhadap harga saham (Sriwahyuni \& Saputra, 2017). Dirangkai berdasarkan hasil - hasil penelitian terdahulu, sehingga dapat ditarik hipotesis 3 penelitian ini adalah Return On Equity berpengaruh terhadap harga saham.

Tujuan dilakukannya penelitian ini adalah untuk mengetahui pengaruh Earning Per Share, Debt to Equity Ratio dan Return On Equity terhadap Harga Saham.

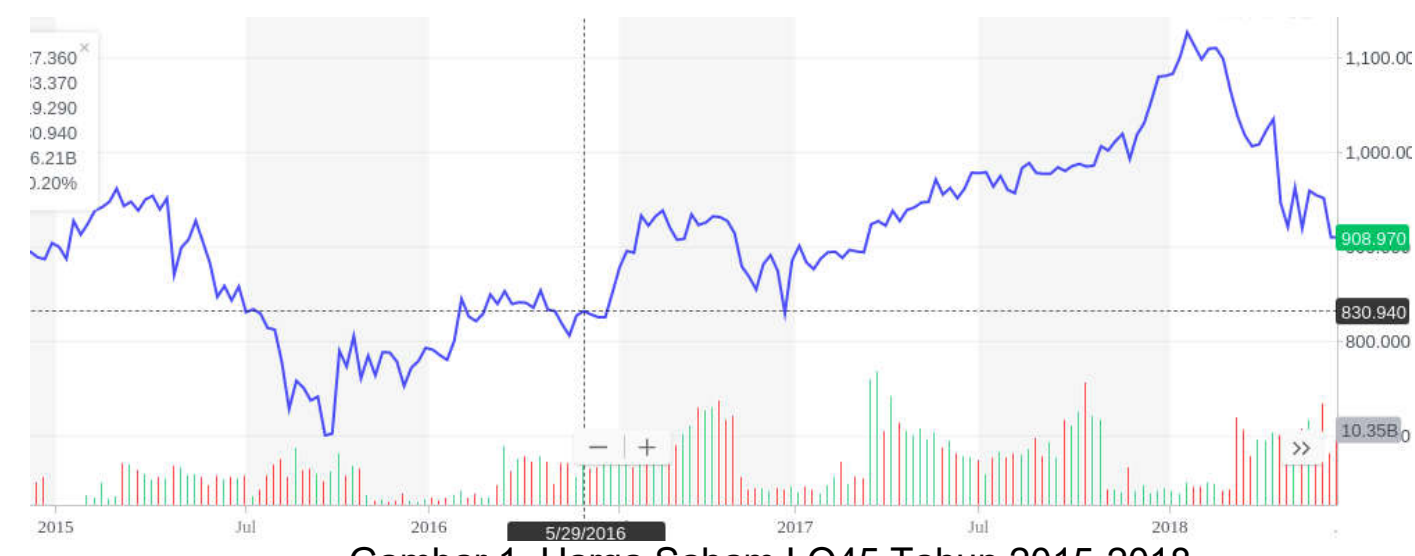

Gambar 1. Harga Saham LQ45 Tahun 2015-2018

\section{Metode Penelitian}

Penelitian ini memiliki kerangka konseptual yang dapat dilihat pada Gambar 1.

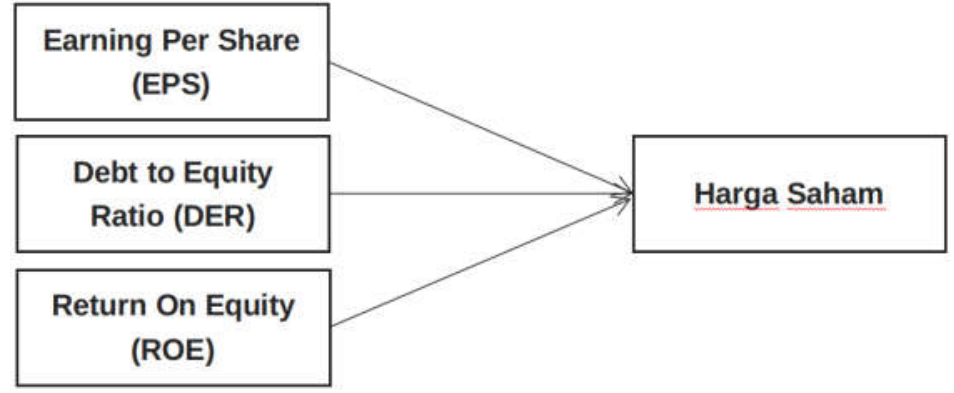

Gambar 2. Model Penelitian

Penelitian ini memiliki tiga hipotesis, yaitu Hipotesis Pertama (H1) Earning Per Share (EPS) berpengaruh terhadap Harga Saham; Hipotesis Kedua (H2) Debt to Equity Ratio (DER) berpengaruh terhadap Harga Saham; Hipotesis Ketiga $(\mathrm{H} 3)$ Return On Equity berpengaruh terhadap Harga Saham. 
JIBEKA

Jurnal IImiah Bisnis dan Ekonomi Asia

ISSN 2620-875X (Online) ISSN 0126-1258 (Print)

http://jurnal.stie.asia.ac.id

Hal. 66-75

Penelitian ini menggunakan data sekunder sebagai sumber data penelitian. Metode pengumpulan data dalam penelitian ini menggunakan metode dokumentasi dan metode studi pustaka.

Populasi dalam penelitian ini adalah perusahaan yang terdaftar dalam indeks LQ45 di BEI periode Februari hingga Juli 2018 dan memiliki pelaporan DER, EPS maupun ROE yang lengkap dan konsisten pada tahun 2017 yang tercantum dalam ringkasan laporan keuangan.

Tabel 2. Sampel Penelitian

\begin{tabular}{|c|c|c|}
\hline NO & CODE & NAMA \\
\hline 1 & $\mathrm{ADHI}$ & Adhi Karya \\
\hline 2 & ADRO & Adaro Energy \\
\hline 3 & AKRA & AKR Corporindo \\
\hline 4 & ANTM & Aneka Tambang \\
\hline 5 & ASII & Astra International \\
\hline 6 & BBCA & Bank BCA \\
\hline 7 & BBNI & Bank BNI \\
\hline 8 & BBRI & Bank BRI \\
\hline 9 & BBTN & Bank BTN \\
\hline 10 & BMRI & Bank Mandiri \\
\hline 11 & BSDE & Bumi Serpong Damai \\
\hline 12 & HMSP & HM Sampoerna \\
\hline 13 & ICBP & Indofood ICBP Sukses Makmur \\
\hline 14 & INCO & Vale Indonesia \\
\hline 15 & INDF & Indofood Sukses Makmur \\
\hline 16 & INTP & Indocement Tunggal Perkasa \\
\hline 17 & JSMR & Jasa Marga \\
\hline 18 & KLBF & Kalbe Farma \\
\hline 19 & LPKR & Lippo Karawaci \\
\hline 20 & LPPF & Matahari Department Store \\
\hline 21 & $\mathrm{MNCN}$ & Media Nusantara Citra \\
\hline 22 & MYRX & Hanson Internasional \\
\hline 23 & PGAS & Perusahaan Gas Negara \\
\hline 24 & PTBA & Tambang Batubara Bukit Asam \\
\hline 25 & PTPP & PP Persero \\
\hline 26 & PWON & Pakuwon Jati \\
\hline 27 & SCMA & Surya Citra Media \\
\hline 28 & SMGR & Semen Indonesia \\
\hline 29 & SRIL & Sri Rejeki Isman \\
\hline 30 & SSMS & Sawit Sumbermas Sarana \\
\hline 31 & TLKM & Telekomunikasi Indonesia \\
\hline
\end{tabular}


JIBEKA

Jurnal IImiah Bisnis dan Ekonomi Asia

ISSN 2620-875X (Online) ISSN 0126-1258 (Print)

http://jurnal.stie.asia.ac.id

Hal. 66-75

\begin{tabular}{|l|l|l|}
32 & UNTR & United Tractor \\
\hline 33 & UNVR & Unilever Indonesia \\
\hline 34 & WIKA & Wijaya Karya \\
\hline 35 & WSKT & Waskita Karya \\
\hline
\end{tabular}

Penelitian ini menggunakan teknik purposive sampling. Dalam penelitian ini, perusahaan yang terindeks LQ45 berjumlah 35 perusahaan dimana kesemuanya telah memenuhi kriteria, yaitu semua perusahaan memiliki data Earning Per Share, Debt to Equity Ratio maupun Return On Equity dan konsisten terindeks LQ45 sejak tahun 2015 sampai 2017. Penelitian ini menggunakan empat variabel yang terdiri dari tiga variabel independen dan satu variabel dependen. Variabel independen terdiri dari Debt to Equity Ratio (DER), Earning Per Share (EPS) dan Return On Equity (ROE). Variabel dependen dalam penelitian ini adalah Harga Saham.

Earning Per Share (EPS) adalah rasio yang digunakan untuk mengetahui seberapa tingkat pengembalian modal untuk setiap satu lembar saham yang dibeli oleh investor di pasar modal. Earning Per Share dihitung menggunakan rumus Earning After Tax dibagi dengan Jumlah Saham yang beredar. Return On Equity (ROE) adalah rasio yang digunakan untuk mengukur kemampuan perusahaan dalam memperoleh laba yang tersedia bagi pemegang saham perusahaan. Return On Equity dihitung menggunakan rumus Earning After Tax dibagi dengan Shareholders Equity. Debt to Equity Ratio (DER) adalah rasio yang digunakan untuk mengetahui seberapa besar risiko yang dimiliki oleh perusahaan yang membandingkan antara earning after tax dan shareholders equity. Semakin rendah DER yang dimiliki oleh perusahaan, maka semakin besar pula kemampuan perusahaan dalam menjamin utang-utangnya dengan ekuitas yang dimiliki. Debt to Equity Ratio dihitung menggunakan rumus total liabilitas dibagi dengan total shareholders equity. Harga Saham adalah harga saham pada saat penutupan atau disebut sebagai closing price. Closing price terbentuk berdasarkan transaksi yang terjadi antara pembeli dan penjual dalam Bursa Efek Indonesia.

Penelitian ini menggunakan analisis regresi linier berganda. Sebelum melakukan analisis regresi linier berganda, variabel-variabel dalam penelitian ini terlebih dahulu dilakukan uji asumsi klasik yang terdiri dari normalitas, multikolinieritas, heterokedastisitas dan autokorelasi.

\section{Hasil Dan Pembahasan}

Objek penelitian yang digunakan dalam penelitian ini adalah perusahaan yang terindeks LQ45 periode tahun 2015-2017. Uji asumsi klasik yang pertama adalah uji normalitas data menggunakan one-sample kolmogorov smirnov test dengan nilai signifikansi sebesar 0,832. Nilai tersebut lebih besar dari 0,05, sehingga data dalam penelitian ini berdistribusi normal.

Uji asumsi klasik yang kedua adalah uji multikolinieritas untuk melihat apakah terjadi keterkaitan diantara variabel - variabel independen yang digunakan dalam penelitian ini. Hasil uji multikolinieritas menunjukkan bahwa Earning Per Share memiliki nilai tolerance sebesar 0,360 dengan VIF sebesar 2,6, kemudian Debt to Equity Ratio memiliki nilai tolerance sebesar 0,280 dengan nilai VIF sebesar 4,357 dan Return On Equity memiliki nilai tolerance sebesar 0,305 dengan nilai VIF sebesar 4,650, sehingga variabel dalam penelitian ini tidak terjadi multikolinieritas.

Uji asumsi klasik yang ketiga adalah uji heterokedastisitas menggunakan uji gletser. Berdasarkan uji gletser, diketahui bahwa Earning Per Share memiliki nilai signifikansi sebesar 0,335, Debt to Equity Ratio memiliki nilai signifikansi sebesar 0,227 dan Return On Equity 


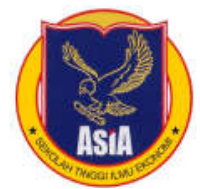

JIBEKA

Jurnal IImiah Bisnis dan Ekonomi Asia

ISSN 2620-875X (Online) ISSN 0126-1258 (Print)

http://jurnal.stie.asia.ac.id

Hal. 66-75

memiliki nilai signifikansi sebesar 0,350 dimana semua variabel memiliki nilai signifkansi lebih besar dari 0,05, sehingga variabel dalam penelitian tidak terjadi heterokedastisitas.

Uji asumsi klasik yang keempat adalah uji autokorelasi, dimana uji autokorelasi dalam penelitian ini menggunakan Runs Test. Hasil pengujian autokorelasi menunjukkan nilai signifikansi 0,827 lebih besar dari 0,05 sehingga variabel yang digunakan dalam penelitian tidak terjadi autokorelasi.

1. Analisis Regresi Linier Berganda

Tabel 3. Analisis Regresi Linier Berganda

\begin{tabular}{|l|c|l|c|c|}
\hline \multirow{2}{*}{ Variabel } & B & Std. Error & $\mathrm{t}$ & Sig. \\
\cline { 2 - 5 } & 1,473 & 0,708 & 1,563 & 0,120 \\
\hline Earning Per Share & 0,731 & 0,210 & 3,817 & 0,000 \\
\hline Debt to Equity Ratio & $-0,370$ & 0,510 & $-0,822$ & 0,254 \\
\hline Return On Equity & 0,244 & 0,231 & 1,051 & 0,203 \\
\hline
\end{tabular}

Berdasarkan Tabel 4, maka diperoleh model persamaan regresi sebagai berikut: $\mathrm{Y}=1,473+0,731 \mathrm{X}_{1}-0,370 \mathrm{X}_{2}+0,244 \mathrm{X}_{3}+\mathrm{e}$

Berdasarkan persamaan regresi tersebut, dapat disimpulkan bahwa dengan nilai konstanta sebesar 1,473 bermakna jika semua variabel independen bernilai konstan maka harga saham adalah 1, 473. Koefisien regresi Earning Per Share sebesar 0,731 bermakna bahwa jika Earning Per Share mengalami peningkatan sebesar 1\% maka harga saham akan mengalami peningkatan sebesar $73 \%$. Koefisien regresi Debt to Equity Ratio sebesar -0,370 bermakna bahwa jika Debt to Equity Ratio mengalami peningkatan sebesar $1 \%$ maka harga saham akan mengalami penurunan sebesar $37 \%$. Koefisien regresi Return On Equity sebesar 0,244 bermakna bahwa jika Return On Equity mengalami peningkatan sebesar $1 \%$ maka harga saham akan mengalami peningkatan sebesar $24 \%$.

2. Uji Hipotesis

Earning Per Share memiliki nilai signifikansi 0,000 < 0,05 sehingga Earning Per Share berpengaruh terhadap harga saham. Berdasarkan hasil uji hipotesis, diketahui bahwa Hipotesis pertama penelitian ini yang menyebutkan Earning Per Share berpengaruh terhadap harga saham diterima. Kemudian, Debt to Equity Ratio memiliki nilai signifikansi 0,254 > 0,05 sehingga Debt to Equity Ratio tidak berpengaruh terhadap harga saham. Berdasarkan hasil uji hipotesis, diketahui bahwa Hipotesis kedua adalah Debt to Equity Ratio berpengaruh terhadap harga saham ditolak. Terakhir yaitu Return On Equity yang memiliki nilai signifikansi 0,203 > 0,05 sehingga Return On Equity tidak berpengaruh terhadap harga saham. Berdasarkan hasil uji hipotesis, diketahui bahwa Hipotesis ketiga adalah Return On Equity berpengaruh terhadap harga saham ditolak.

3. Koefisien Determinan

Nilai Adjusted $R$ Square sebesar 0,670 yang bermakna bahwa variabel yang digunakan dalam penelitian ini yaitu Earning Per Share, Debt to Equity Ratio dan Return On Equity mampu menerangkan Harga Saham sebesar $67 \%$ dimana sisanya yaitu $33 \%$ dijelaskan oleh variabel lain yang diteliti.

4. Pembahasan

Hasil uji hipotesis menunjukkan bahwa Earning Per Share berpengaruh terhadap harga saham. Pengaruh tersebut bermakna bahwa dalam melakukan investasi saham, Earning Per Share menjadi indikator utama investor. Ketika terjadi perubahan dalam bentuk peningkatan Earning Per Share maka harga saham juga akan mengalami 


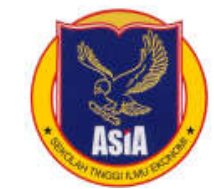

JIBEKA

Jurnal IImiah Bisnis dan Ekonomi Asia

ISSN 2620-875X (Online) ISSN 0126-1258 (Print)

http://jurnal.stie.asia.ac.id

Hal. 66-75

perubahan berupa peningkatan. Data ini menunjukkan bahwa perusahaan yang terindeks LQ45 merupakan pilihan terbaik bagi investor untuk menginvestasikan dana, karena Earning Per Share menunjukkan tingkat minat investor terhadap harga saham perusahaan. Hasil penelitian ini mendukung penelitian yang dilakukan oleh Suherman (2017), Ginsu et al., (2017), Hasanah et al., (2017), Egam et al., (2017), Sriwahyuni \& Saputra (2017), Saryadi (2016) yang menemukan bahwa Earning Per Share berpengaruh terhadap harga saham ((Egam et al., 2017; Ginsu, Saerang, \& Roring, 2017; Hasanah et al., 2017; Saryadi, 2016; Sriwahyuni \& Saputra, 2017; Suherman, 2017).

Hasil uji hipotesis menunjukkan bahwa Debt to Equity Ratio tidak berpengaruh terhadap harga saham. Tidak pengaruh tersebut bermakna bahwa Debt to Equity Ratio tidak menjadi indikator utama investor untuk melakukan investasi saham pada perusahaan terindeks LQ45. Makna lain adalah, ketika terjadi perubahan Debt to Equity Ratio maka tidak akan menyebabkan harga saham mengalami perubahan baik penurunan maupun peningkatan. Hal ini juga menunjukkan bahwa investor lebih fokus pada hasil atau pendapatan perusahaan dibandingkan dengan proses bagaimana perusahaan melakukan pengelolaan sehingga mendapatkan pendapatan. Hasil penelitian ini mendukung penelitian yang dilakukan oleh Utomo et al., (2016) dan Nurfadillah (2011) yang menemukan bahwa Debt to Equity Ratio tidak berpengaruh terhadap harga saham (Nurfadillah, 2011; Utomo, Andini, \& Raharjo, 2016).

Hasil uji hipotesis menunjukkan bahwa Return On Equity tidak berpengaruh terhadap harga saham. Tidak pengaruh tersebut bermakna bahwa ketika terjadi perubahan pada Return On Equity tidak akan menyebabkan perubahan pada harga saham, baik berupa peningkatan maupun penurunan. Hal ini mengindikasikan bahwa investor memiliki sudut pandang positif terhadap perusahaan LQ45, yaitu walaupun sumber modal yang digunakan untuk operasional perusahaan berasal dari utang, tidak akan mempengaruhi terhadap minat investor untuk menginvestasikan dana pada perusahaan LQ45, terlebih perusahaan tersebut memiliki Earning Per Share yang tinggi. Hasil penelitian ini mendukung penelitian yang dilakukan oleh Utomo et al., (2016), Egam et al., (2017), Aisah \& Mandala (2016) yang menemukan bahwa Return On Equity tidak berpengaruh terhadap harga saham (Aisah \& Mandala, 2016; Egam et al., 2017; Utomo et al., 2016).

\section{Kesimpulan}

Berdasarkan hasil penelitian yang telah dilakukan, maka kesimpulan penelitian ini adalah Earning Per Share merupakan indikator utama bagi investor untuk menginvestasikan dananya pada perusahaan terindeks LQ45, sedangkan Debt to Equity Ratio serta Return On Equity tidak menyebabkan perubahan terhadap minat investor untuk menginvestasikan dananya pada perusahaan terindeks LQ45. Apabila perusahaan terindeks LQ45 ingin meningkatkan minat investor untuk menginvestasikan dananya pada perusahaan LQ45 maka yang harus dilakukan adalah secara konsisten meningkatkan Earning Per Share perusahaan, dimana apabila dalam proses tersebut perusahaan LQ45 harus meningkatkan jumlah utang dan kemampuan perusahaan dalam mengembalikan utang tersebut rendah tidak akan mengurangi minat atau ketertarikan investor untuk menginvestasikan dananya pada perusahaan terindeks LQ45. Saran bagi peneliti selanjutnya adalah agar menambahkan variabel lain seperti Return On Asset, Book Value serta Devidend. 
JIBEKA

Jurnal IImiah Bisnis dan Ekonomi Asia

ISSN 2620-875X (Online) ISSN 0126-1258 (Print)

http://jurnal.stie.asia.ac.id

Hal. 66-75

\section{Daftar Pustaka}

Aisah, A. N., \& Mandala, K. (2016). Pengaruh Return On Equity, Earning Per Share, Firm Size dan Operating Cash Flow Terhadap Return Saham. E-Jurnal Manajemen Unud, 5(11), 6907-6936.

Egam, G. E. Y., Ilat, V., \& Pangerapan, S. (2017). Pengaruh Return On Asset (ROA), Return On Equity (ROE), Net Profit Margin (NPM), Dan Earning Per Share (EPS) Terhadap Harga Saham Perusahaan Yang Tergabung Dalam Indeks LQ45 Di Bursa Efek Indonesia Periode Tahun 2013-2015. Jurnal EMBA, 5(1), 105-114.

Ginsu, F. F., Saerang, I. S., \& Roring, F. (2017). Pengaruh Earning Per Share (EPS) dan Return On Equity (ROE) Terhadap Harga Saham. Jurnal EMBA, 5(2), 1327-1336.

Halim, A., Basri, H., \& Faisal. (2016). Pengaruh Itellectual Capital Terhadap Profitabilitas Dan Dampaknya Terhadap Harga Saham Perusahaan Sektor Keuangan Yang Terdaftar Di Bursa Efek Indonesia (BEI). Jurnal Bisnis Dan Ekonomi (JBE), 23(2), 124-141.

Hasanah, Z., Wahono, B., \& Salim, M. A. (2017). Pengaruh Price Earning Ratio (PER), Earning Per Share (EPS), Return On Asset (ROA), dan Debt To Equity Ratio (DER) Terhadap Harga Saham Perusahaan Food and Beverages yang Terdaftar di Bursa Efek Indonesia (BEI) (Studi Empiris pada Perusahaan Food and Beve. Jurnal Riset Manajemen, 6(1).

Kumaidi, R. K., \& Asandimitra, N. (2017). Pengaruh ROA, ROE, DER, DPR, Dan LDR Terhadap Harga Saham Sektor Perbankan BEl Periode 2011 - 2016 (Dengan Penggolongan Kapitalisasi Kecil dan Kapitalisasi Besar ). Jurnal IImu Manajemen, 5(3), 1-13.

Lacinka, A., Fathoni, A., \& Gagah, E. (2018). Analyze Effect of Debt To Equity Ratio, Net Profit Margin, and Earning Per Share to the Company's Stock Prices LQ45 Listed on the Indonesia Stock Exchange. Journal of Management, 4(4).

Masruri, M. (2012). Pengaruh Price Earning Ratio , Return On Equitity dan Debt to Equitity Ratio Terhadap Return Saham Sektor Jasa Keuangan di Bursa Eefek Indonesia Periode Tahun 2008 - 2010, 5, 42-47.

Nurfadillah, M. (2011). Analisis Pengaruh Earning Per Share, Debt To Equity Ratio dan Return On Equity terhadap Harga Saham PT UNILEVER INDONESIA Tbk. Jurnal Manajemen Dan Akuntansi, 12(1), 45-50.

Ramadhani, Y. C., \& Arnomo, I. (2014). Pengaruh Debt to Equity Ratio (DER), Return On Asset (ROA) dan Earning Per Share (EPS) terhadap Harga Saham pada Industri Perbankan yang Terdaftar di Bursa Efek Indonesia. Vol. 7, No. 2, Desember 2014, 10(1), 27-36.

Saryadi, N. D. (2016). Pengaruh Suku BUnga (BI Rate), EPS dan ROE terhadap Harga Saham Pada Perusahaan Sektor Pertambangan yang TErdaftar di BUrsa Efek Indonesia Periode 2010-2014. Jurnal Administrasi Bisnis, 5(2), 95-104.

Sriwahyuni, E., \& Saputra, R. S. (2017). Pengaruh CR, DER, ROE, TAT, dan EPS terhadap Harga Saham Industri Farmasi di BEI Tahun 2011-2015. Jurnal Online Insan Akuntan, 
2(1), 119-136.

Suherman. (2017). Pengaruh Earning Per Share (EPS) Terhadap Harga Saham pada PT. Pabrik Kertas Tjiwi Kimia, Tbk. dan Entitas Anak. Jurnal FinAcc, 1(11), 1983-1993.

Utomo, W., Andini, R., \& Raharjo, K. (2016). Pengaruh Leverage (DER), Price Book Value (PBV), Ukuran Perusahaan (SIZE), Return On Equity (ROE), Deviden Payout Ratio (DPR) dan Likuiditas (CR) Terhadap Price Earning Ratio (PER) Pada Perusahaan Manufaktur Yang Listing di BEI Tahun 2009 - 2014. Journal Of Accounting, 2(2). 